\title{
PROFIL KEMAMPUAN MEMBACA SISWA KELAS 5 SEKOLAH DASAR (SD) DAN MADRASAH IBTIDAIYAH (MI) DITINJAU DARI JENIS SEKOLAH DAN JENIS KELAMIN
}

\author{
Rifa Hidayah \\ Dosen Tetap fakultas psikologi UIN Maulana Malik Ibrahim Malang
}

\begin{abstract}
Abstrak
This study wanted to test the reading ability of students in grade 5 elementary school and madrasah, aged 9-11 years in terms of gender and type of school. Data collection tool tests the ability to read and the data entry student sex and type of school that consists of Elementary and MI. Research subjects amounted to 71 students from two schools, which consists of 43 elementary school students and 28 students MI. The results of data analysis showed that there was no difference between reading ability between men and women $(p>0.05)$. In review of the types of schools that is students from elementary school and MI ( $p>00.5)$ and no difference in reading ability.
\end{abstract}

Key words: Ability to read, gender, type of school

\section{A.PENDAHULUAN}

Aktivitas belajar pada anak di mulai dari bagaimana individu membaca. Proses membaca buku akan sangat di pentingkan bagi anak untuk kehidupan mendatang, dengan aktivitas membaca anak tidak akan ketinggalan abad informasi, karena jawaban untuk krisis pendidikan adalah buku (Leonhardt, 1999). Anjuran Islam untuk pertama kali pada turunnya wahyu adalah adalah 'iqra' yang berarti bacalah (tertera dalam surat al-Alaq ayat 1-5), ini mengandung makna betapa pentingnya kemampuan membaca. Kemampuan membaca merupakan suatu hal yang 


\section{Rifa Hidayah - Profil Kemampuan Membaca Siswa Kelas 5 SD \& MI}

amat penting dalam masyarakat terpelajar (Burns, 1996) sekaligus menjadi dasar bagi penguasaan ketrampilan akademik siswa pada semua bidang.

Namun sayangnya masih banyak siswa SD/MI kelas tinggi yang mengalami rendah kemampuan membacanya. Siswa yang mengalami kemampuan membaca rendah, seperti terlihat dari fenomena banyaknya siswa yang gagal ujian nasional pada mata pelajaran Bahasa Indonesia (Kompas, 2 Juni 2010).

Dibanding negara-negara lain, kemampuan membaca anak-anak Indonesia tergolong rendah. Hasil Penelitian yang dilakukan Tim Program of International Student Assessment (PISA) di Indonesia dengan sampel penelitian 7.355 siswa usia 15 tahun dari 290 sekolah pada tahun 2003, menunjukkan bahwa kemampuan membaca pemahaman siswa Indonesia sangat memprihatinkan, sekitar $37,6 \%$ dari siswa hanya bisa membaca tanpa bisa menangkap maknanya, dan sebanyak 24,8\% hanya bisa mengaitkan teks yang dibaca dengan satu informasi pengetahuan (Kompas, 2010).

Di Jawa Timur, prosentase penduduk berusia 10 tahun lebih yang tidak bisa membaca atau buta huruf adalah $12,20 \%$ pada tahun 2009 . Hal ini mencemaskan karena persentase penduduk Indonesia secara keseluruhan yang tidak bisa membaca jauh lebih rendah yaitu 7,42\% (BPS, 2009). Penelitian Rofiudin (2003) yang melibatkan 964 siswa kelas 5 SDN di pulau Jawa menunjukkan bahwa skor rerata kemampuan membaca siswa rendah yaitu 33,039, hal ini menunjukkan bahwa kemampuan siswa kelas 5 SD masih jauh dari yang diharapkan. Padahal sesuai dengan taraf perkembangan kognitif siswa kelas 5 SD berada pada periode ketiga yaitu pada stadium operasional kongkrit dari Piaget (7-11 tahun), anak mulai berfikir logis tentang kejadian kongkrit dan mampu menggunakan metakognisi dalam mengkontruksi bacaan (Crain, 2007)

Sesuai dengan tahap perkembangan membaca, siswa kelas 5 SD/MI (usia 9-11) berada pada tahap ketiga (Chall, dalam Kumara, 2010) umumnya anak pada usia tersebut membaca adalah untuk belajar, dan anak dituntut mampu menguasai informasi dari materi tertulis dan

61 Madrasah, Vol. 4 No. 1 Juli-Desember 2011 


\section{Rifa Hidayah - Profil Kemampuan Membaca Siswa Kelas 5 SD \& MI}

memahami apa yang dibaca. Idealnya siswa yang duduk di kelas tinggi, sudah mempunyai kemampuan yang memadai dalam memahami suatu bacaan sebagai tindak lanjut membaca permulaan (Rahim, 2008). Namun kenyataannya masih banyak siswa kelas $5 \mathrm{SD} / \mathrm{MI}$ yang mengalami problem membaca dengan belum mampu memahami bacaan (Rofiudin, 2003).

Sungguh sayang bila kurang pedulinya masyarakat terhadap masalah kemampuan membaca yang rendah di kalangan anak-anak ini terus berlanjut. Dengan demikian memahami kemampuan membaca siswa kelas $5 \mathrm{SD} / \mathrm{MI}$ sangat penting dilakukan. Salah satu faktor penting yang mendukung kemampuan membaca pada anak dilihat dari jenis kelamin. Kemampuan membaca perempuan lebih tinggi dibanding laki-laki disebabkan karena perkembangan otak kiri perempuan lebih berkembang (Yasmine, 2007) dan sebagian besar pusat membaca yang utama terletak di belahan otak kiri hemisphere (Feifer \& DeFina, 2001). Sebaliknya menurut Secara historis, proporsi yang lebih tinggi dari perempuan berprestasi lebih tinggi dalam mmebaca di banding laki-laki. Studi PISA (Programme for International Student Assessment) yaitu studi literasi yang bertujuan untuk meneliti secara berkala tentang kemampuan siswa usia 15 tahun (kelas III SMP dan Kelas I SMA) dalam membaca (reading literacy), matematika (mathematics literacy), dan sains (scientific literacy) menunjukkan adanya perbedaan pencapaian literasi antara laki-laki dan perempuan, di mana perempuan menggungguli pria dalam kemampuan membaca. Secara umum, di semua negara terkecuali di Liechtenstein, perempuan memperoleh nilai lebih unggul dibanding laki-laki, dan di Indonesia memperlihatkan perbedaan pencapaian yang cukup tinggi (Yusuf, 2006).

Selain perbedaan jenis kelamin, penting melihat kemampuan membaca ditinjau dari jenis sekolah. Yang dimaksud jenis sekolah di sini adalah SD dan MI. Sekolah Dasar (SD) adalah jenjang paling dasar pada pendidikan formal di Indonesia, ditempuh dalam waktu 6 tahun, mulai dari Kelas 1 sampai Kelas 6. Madrasah Ibtidaiyah (MI) adalah jenjang paling dasar pada pendidikan formal di Indonesia, setara dengan Sekolah Dasar, yang pengelolaannya dilakukan oleh kementrian Agama.

62 Madrasah, Vol. 4 No. 1 Juli-Desember 2011 


\section{Rifa Hidayah - Profil Kemampuan Membaca Siswa Kelas 5 SD \& MI}

Berdasarkan Puslitbang (2006) menunjukkan dari 171.651 Sekolah Dasar dan Madrasah Ibtidaiyah maka 21.454 atau 12\% di antaranya adalah Madrasah dan dari jumlah terbesar dari lembaga pendidikan Madrasah berstatus sebagai Madrasah Swasta. Sebagai contoh, di kota Malang dari jumlah MI yang berstatus Negeri hanya 2, yaitu MIN 1 dan MIN 2, sedangkan yang lain MIS, padahal untuk sekolah SD banyak didominasi oleh jumlah SD Negeri.

Pada dasarnya kurikulum Madrasah Ibtidaiyah sama dengan kurikulum Sekolah Dasar, hanya saja pada MI terdapat porsi lebih banyak mengenai Pendidikan Agama Islam. Sesuai ketetapan SKB 3 Menteri 1975, bahwa Madrasah dengan beban kurikulum 70\% umum dan 30\% agama. Dengan demikian Madrasah adalah Sekolah Umum, berciri khas Agama Islam, dimana selain mengajarkan mata pelajaran sebagaimana Sekolah Dasar, juga ditambah dengan pelajaran-pelajaran seperti: Alquran Hadits, Aqidah Akhlak, Fiqih, Sejarah Kebudayaan Islam dan Bahasa Arab.

Madrasah lebih unggul dalam bidang agamanya, namun dari segi kualitas Madrasah masih rendah dibandingkan sekolah umum (Shaleh, 2004), sedangkan untuk materi pendidikan umum termasuk kemampuan membaca siswa madrasah Ibtidaiyah cenderung lebih rendah di banding sekolah umum, hal ini dapat dilihat dari nilai USBN di tingkat SD/MI tahun 2010 di jawa timur, pemerolehan nilai MI lebih rendah dibanding SD masih di bawah SD.

Mengingat urgensinya kemampuan membaca maka penelitian ini akan dilakukan di SD (sekolah dasar) dan MI. MI (Madrasah Ibtidaiyah) yang berada di bawah naungan Kementrian Agama. Penelitian ini dilakukan di MI dan SD karena ingin melihat perbedaan kemampuan membaca siswa kelas 5 yang berasal dari SD dan MI. Berdasarkan latar belakang di atas, perumusan masalahnya yaitu pada tingkatan apa kemampuan membaca anak-anak? dan apakah ada perbedaan kemampuan membaca antara siswa laki-laki dan siswa perempuan? Apakah ada perbedaan antara kemampuan membaca siswa ditinjau dari jenis sekolah yang berasal dari SD dan siswa yang berasal dari MI?

63 Madrasah, Vol. 4 No. 1 Juli-Desember 2011 


\section{Rifa Hidayah - Profil Kemampuan Membaca Siswa Kelas 5 SD \& MI}

\section{B. KAJIAN TEORI}

\section{Kemampuan membaca}

Membaca merupakan komunikasi pikiran atau perasaan antara penulis dengan pembaca (Burns, et al., 1996; Tarigan, 2008). Oleh karena membaca itu merupakan komunikasi, maka serangkaian kemampuan harus dimiliki seseorang bila individu ingin mempunyai kemampuan membaca yang baik. Serangkaian kemampuan itu antara lain kemampuan untuk mempersepsikan kata dan kalimat secara tepat, kemampuan untuk mengidentifikasikan huruf secara jelas, kemampuan untuk mengidentifikasikan kata, kemampuan memahami kata dan kalimat, kemampuan untuk mengidentifikasikan gagasan pokok bacaan, kemampuan untuk mengingat, serta kemampuan mengevaluasi seluruh bacaan yang dihadapinya (Crawley \& Mountain, 1995; Miller, 1993; Sternberg dalam Fletcher, 2002).

Seseorang dikategorikan sebagai mampu membaca dengan baik bila ia mampu memahami isi bacaan itu. Kriteria tentang kemampuan membaca yang baik itu bergantung pada tiga aspek (Alderson, 2000). Aspek pertama pemahaman literal yaitu memahami dan mengingat informasi secara tepat seperti yang dimaksudkan oleh penulisnya (Syafi'i, 1994). Pemahaman literal merupakan pemahaman yang paling sederhana atau paling mendasar dan hanya memerlukan sedikit kegiatan berpikir.

Aspek kedua kemampuan membaca adalah pemahaman inferensial ialah menarik kesimpulan dari informasi yang tertulis berdasarkan intuisi dan pengalaman pembaca. Kemampuan inferensial ini melibatkan ketrampilan berpikir yang lebih rumit karena ia harus bisa mengidentifikasikan gagasan dan makna secara implisit dari suatu bacaan.

Membaca kritis ialah kemampuan memberikan penilaian materi wacana berdasarkan pengalaman, pengetahuan dan kriteria sendiri. Kemampuan ini tidak hanya menuntut kemampuan menginterpretasi isi bacaan, tetapi juga kemampuan untuk menilai isi bacaan. Pembaca harus

64 Madrasah, Vol. 4 No. 1 Juli-Desember 2011 


\section{Rifa Hidayah - Profil Kemampuan Membaca Siswa Kelas 5 SD \& MI}

mampu secara kritis menilai gagasan-gagasan yang disampaikan penulis dan menilai kesahihan dari apa yang disampaikannya itu.

\section{Perbedaan jenis kelamin dan jenis sekolah terhadap kemampuan membaca}

Jenis kelamin merupakan jenis dari identifikasi manusia yang terdiri atas jenis kelamin laki-laki dan perempuan. Peran jenis kelamin menurut Aaron et.al (2008) juga berkorelasi terhadap kemampuan membaca. Selama masa sekolah dasar dan menengah ada bukti kuat bahwa perempuan lebih unggul ketimbang laki-laki dalam hal membaca dan menulis (Santrock, 2004). Umumnya perempuan mengungguli lakilaki dalam kemampuan verbal, sedangkan laki-laki lebih trampil dalam matematika (Santrock, 2004). Meskipun begitu sejak tahun 1970 laki-laki memiliki pemerolehan dalam kemampuan verbal dan superior dalam metematika. Seringkali laki-laki difikirkan olah guru menjadi lebih energik, penuh semangat, dan sulit dikontrol. Mereka lebih banyak interaksi bahasa dengan perempuan dibandingkan laki-laki, di rumah maupun di sekolah laki-laki memandang bahasa sebagai feminis.

Pendapat ini diperkuat oleh Miller, (1993) yang menyatakan perbedaan Jenis kelamin berkorelasi dengan prestasi membaca. Penelitian Miller (1993) telah dilakukan di berbagai negara termasuk di Jerman dimana laki-laki lebih baik kemampuanya dalam membaca dibandingkan perempuan. Di Kanada perempuan lebih baik, di Ingris laki-laki lebih baik, di israil laki-laki dan perempuan sama-sama. Di USA menunjukkan perempuan lebih baik dalam berbahasa umur 9,13, 17. Perbedaan gender dalam prestasi membaca mungkin sebagai contoh dari prediksi pemenuhan diri, di mana guru di USA melihat perempuan lebih ahli dibanding laki-laki. Laki-laki memiliki kemampuan membaca lebih rendah dibanding perempuan, sebagaimana surver USA Department of Education (Kantor Program Pendidikan Khusus, 2006) menunjukkan tingginya jumlah laki-laki dengan ketidakmampuan belajar termasuk kesulitan belajar dalam membaca.

65 Madrasah, Vol. 4 No. 1 Juli-Desember 2011 


\section{Rifa Hidayah - Profil Kemampuan Membaca Siswa Kelas 5 SD \& MI}

Laki-laki beresiko lebih tinggi mengalami gangguan perkembangan bahasa dan disleksia (Tallal, 2004), Rasio laki dan perempuan yang mengalami kesulitan memebaca adalah 1;1 sampai 4;1 (Penington, 1991, Feifer \& deFina, 2001, Fitch \& Pfeiffers, 2004; Tallal, 2004). Pendapat Rutter dan Yule (Woodward, 2002) laki-laki lebih besar 3,3 \% lebih banyak beresiko mengalami kesuliran membaca dibanding perempuan dengan dengan tingkat prevalensi laki-laki dan perempuan yang mengalami kesulitan membaca di lihat dari perbedaan gender karena laki-laki seringkali lebih terbuka dalam ekspresi frustrasi dan kesulitan membacanya (Shaywit, 1999; Curry, 2006).

Di Jawa Timur berdasarkan penelitian Nawangsari (2008) mengenai identifikasi kesulitan belajar menunjukkan bahwa dari 510 siswa kelas IV hingga VI SD di Surabaya terdapat sampel 112 siswa terdapat $19.8 \%$ teridentifikasi mengalami gangguan kesulitan belajar, dan dari prosentase tersebut sebanyak 78,5\%, dalam mengalami gangguan kesulitan belajar membaca, dan dilihat dari jenis kelamin, siswa laki-laki menunjukkan prosentase yang lebih tinggi dibanding siswa perempuan dengan prosentase laki-laki 53.6\% dan perempuan $46.4 \%$.

Studi PISA (Programme for International Student Assessment) yaitu studi literasi yang bertujuan untuk meneliti secara berkala tentang kemampuan siswa usia 15 tahun (kelas III SMP dan Kelas I SMA) dalam membaca (reading literacy), matematika (mathematics literacy), dan sains (scientific literacy) menunjukkan adanya perbedaan pencapaian literasi antara laki-laki dan perempuan, di mana perempuan menggungguli pria dalam kemampuan membaca. Tingkat perbedaannya kemampuan membaca laki-laki dan perempuan dapat dilihat dari studi PISA tahun 2000, yang menunjukkan bahwa diberbagai negara termasuk Indonesia secara umum perempuan memiliki kemampuan membaca lebih baik dibandingkan laki-laki.

Membaca juga sangat dipengaruhi oleh lingkungan sekolah. Secara geografis, penyebaran Madrasah swasta lebih banyak di pedesaan dan kalangan masyarakat menengah ke bawah. Madrasah Swasta saat ini 


\section{Rifa Hidayah - Profil Kemampuan Membaca Siswa Kelas 5 SD \& MI}

merupakan satu-satunya pilihan masyarakat yang rendah daya dukung ekonominya, di tengah mahalnya biaya pendidikan. Kebanyakan orangtua siswa Madrasah adalah petani yang hidup secara tradisional, berpendidikan rendah dan kebanyakan hidup didaerah pedesaan atau di pinggiran kota (Yusuf, 2006).

Sarana prasarana Madrasah masih sangat sederhana, perlengkapan seadanya, kemampuan manajemen rendah dan tenaga guru kebanyakan dilatar belakangi oleh semangat ibadah yang sangat tidak selektif terhadap persyaratan yang diperlukan. Padahal lingkungan di sekolah yang kurang mendukung kemampuan anak akan memperburuk potensi anak, terutama anak-anak akan mengalami kesulitan membaca. Keadaan demikian dapat mengakibatkan prestasi belajar siswa rendah. Apalagi materi yang dipelajari di madrasah prosentasenya jauh lebih banyak di banding siswa Madrasah. Selain itu sifat dari lingkungan kelas dan sekolah dapat memperburuk situasi. Biggs (dalam Law, 2008) menjelaskan bahwa kelas adalah lingkungan belajar yang baik yang mana kegiatan-kegiatan siswa menekankan adanya iklim belajar yang hangat, sehingga memberikan hasil yang tinggi pada prestasi belajar siswa.

Berdasarkan penelitian tersebut menunjukkan meskipun masih terdapat hasil yang kontradiktif antara apakah laki-laki ataukah perempuan yang lebih baik kemampuan membacanya, relevan dan penting untuk diteliti. Hipotesa yang diajukan dalam penelitian ini adalah:

H1: Perempuan lebih tinggi kemampuan membacanya dibanding laki-laki.

H2: Siswa SD lebih tinggi kemampuan membacanya dibanding siswa MI.

\section{METODE PENELITIAN}

Variabel independent/bebas dalam penelitian ini adalah jenis kelamin (laki-laki dan perempuan) dan jenis sekolah (SD dan MI). Sedangkan variabel dependent atau tergantung dalam peneltian ini adalah kemampuan membaca.

67 Madrasah, Vol. 4 No. 1 Juli-Desember 2011 


\section{Rifa Hidayah - Profil Kemampuan Membaca Siswa Kelas 5 SD \& MI}

\section{Definisi Operasional Kemampuan membaca}

Kemampuan membaca merupakan kemampuan memahami isi teks bacaan atau wacana yang dibaca yang mencakup pemahaman literal, pemahaman inferensial, pemahaman kritis. Kemampuan membaca diukur dengan tes membaca terdiri atas 36 aitem yang disusun oleh penulis berdasarkan tiga Indikator kemampuan membaca yaitu pemahaman literal, pemahaman inferensial, membaca kritis atau evaluasi (Alderson, 2000; Barret, (Haris \& Sipay, 1980), Burns, et al., 1996; Haris \& Sipay, 1980; KTSP, 2006). Pemahaman literal terdiri atas 12 aitem dan pemahaman inferensial terdiri atas 12 aitem dan pemahaman kritis adalah 12 aitem.

Bahan tes membaca diambil dari buku bacaan umum, majalah, dan soal-soal bahasa Indonesia untuk kelas V SD/MI yang sesuai dengan kurikulum KTSP 2006. Semakin tinggi skor yang diperoleh berarti semakin tinggi kemampuan membacanya, sebaliknya semakin rendah skor yang diperoleh berarti semakin rendah kemampuan membacanya.

\section{Jenis kelamin}

Jenis kelamin merupakan identitas yang melekat pada diri seseorang yang terdiri atas dua jenis laki-laki dan perempuan. Karakteristik jasmani yang membedakan anak sebagai laki-laki atau perempuan, sebagaimna dinyatakan oleh subjek penelitian dalam pernyataan identitas diri.

\section{Jenis sekolah}

Identitas sekolah yang dimaksud di sini adalah SD dan MI. Yaitu sekolah yang berada di bawah naungan Kamenag dan Diknas. SD merupakan sekolah dasar di bawah naungan Departemen pendidikan, dan MI merupakan sekolah dasar di bawah naungan Kementrian Agama Kota Madya Malang, atau disebut MI (Madrasah Ibtidaiyah).

\section{Subjek penelitian}

Anggota sampel penelitian berjumlah 71 siswa yang terdiri atas 43 siswa kelas $5 \mathrm{SDN}$ “ $X$ ” malang dan 28 siswa MI “ $X$ ' Malang.

68 Madrasah, Vol. 4 No. 1 Juli-Desember 2011 


\section{Rifa Hidayah - Profil Kemampuan Membaca Siswa Kelas 5 SD \& MI}

\section{Analisis data}

Analisis data penelitian uji compare means dan anova menggunakan bantuan komputer program SPSS. Adapun pengujian hipotesa yang dipakai dalam penelitian adalah dengan menggunakan pedoman pengujian sebagai berikut: (a). Hipotesa diterima jika $\mathrm{r}_{\text {hit }}<\mathrm{r}_{\text {tab }} 5 \%$ atau $\mathrm{p}<$ 0,05 yakni ada perbedaan yang signifikan antara kemampuan membaca laki-laki dan perempuan serta ada perbedaan yang signifikan kemampuan membaca antara siswa yang berasal dari SD dan MI (b). Hipotesa diterima jika $\mathrm{r}_{\text {hit }}<\mathrm{r}_{\text {tab }} 1 \%$ atau $\mathrm{p}<0,01$ yakni ada perbedaan yang sangat signifikan antara antara kemampuan membaca laki-laki dan perempuan serta ada perbedaan yang sangat signifikan kemampuan membaca antara siswa yang berasal dari SD dan MI (c). Hipotesa ditolak jika $r_{\text {hit }}>r_{\text {tab }} 5 \%$ atau $p>$ 0,05 yakni tidak ada perbedaan kemampuan membaca laki-laki dan perempuan serta ada perbedaan yang sangat signifikan kemampuan membaca antara siswa yang berasal dari SD dan MI

\section{HASIL PENELITIAN}

\section{Tingkatan kemampuan membaca siswa kelas 5 SD/MI}

Tingkat kemampuan membaca dalam penelitian ini dilihat dengan perolehan skor tes kemampuan membaca. Setelah di lihat dari skor tes kemampuan membaca maka akan dibandingkan antara skor rerata hipotetik dan rerata empirik. Data kemampuan membaca dengan menggunakan tes membaca yang berjumlah 36 aitem. Skor yang salah nilai 0 dan skor benar nilai 1 , skor terendah 0 dan skor tertinggi adalah 18 . Skor rerata hipotetik ada lah $(0=36) / 2=18$.

Tabel I. Hasil statistik deskripsi tes kemampuan membaca

\begin{tabular}{|l|l|l|l|c|c|c|}
\hline & $\mathrm{N}$ & Minimum & Maximum & $\begin{array}{c}\text { Mean } \\
\text { hipotetik }\end{array}$ & $\begin{array}{c}\text { Mean } \\
\text { empirik }\end{array}$ & $\begin{array}{c}\text { Std. } \\
\text { Deviation }\end{array}$ \\
\hline
\end{tabular}

69 Madrasah, Vol. 4 No. 1 Juli-Desember 2011 
Rifa Hidayah - Profil Kemampuan Membaca Siswa Kelas 5 SD \& MI

\begin{tabular}{|l|r|r|r|r|r|r|}
\hline $\begin{array}{l}\text { Membaca } \\
\text { Valid N } \\
\text { (listwise) }\end{array}$ & 71 & 10.00 & 30.00 & 18.000 & 16.8169 & 4.48588 \\
\hline
\end{tabular}

Hasil statistik menunjukkan bahwa mean $=16.8169$ dan standar deviasi $=4,485$. Analisi data tersebut menggambarkan bahwa skor rerata hipotetik lebih tinggi dibandingkan dengan skor rerata empirik, yaitu 16.8169 berbanding 18 .

Berdasarkan hasil tersebut dapat disimpulkan bahwa kemampuan membaca siswa kelas 5 SD dan MI adalah rendah. Prosentase siswa yang mempunyai skor di bawah 18 sebanyak 60,5\% (42 siswa).

\section{Perbedaan kemampuan membaca di tinjau dari jenis kelamin}

Untuk mengetahui adanya perbedaan kemampuan membaca antara laki-laki dan perempuan bisa diuji dengan anava dan uji komparasi means dari masing-masing jenis kelamin. Hasil dari uji komparasi $\mathrm{r}$ adalah sebagai berikut

Tabel II. Hasil mean kemampuan membaca berdasarkan jenis kelamim siswa SD/MI

\begin{tabular}{|c|c|c|c|}
\hline jeniskelamin & Mean & $\mathrm{N}$ & $\begin{array}{c}\text { Std. } \\
\text { Deviation }\end{array}$ \\
\hline Perempuan & 16.3714 & 35 & 3.08779 \\
\hline laki-laki & 17.2500 & 36 & 5.53108 \\
\hline Total & 16.8169 & 71 & 4.48588 \\
\hline
\end{tabular}

70 Madrasah, Vol. 4 No. 1 Juli-Desember 2011 
Rifa Hidayah - Profil Kemampuan Membaca Siswa Kelas 5 SD \& MI

Tabel III. Analisis uji beda kemampuan membaca bedasarkan jenis kelamin

ANOVA Tablea

\begin{tabular}{|ll|r|r|r|r|r|}
\hline & $\begin{array}{c}\text { Sum of } \\
\text { Squares }\end{array}$ & df & $\begin{array}{c}\text { Mean } \\
\text { Square }\end{array}$ & F & Sig. \\
\hline $\begin{array}{llrlrl}\text { Membaca * } \\
\text { jeniskelamin }\end{array}$ & Between Groups & 13.698 & 1 & 13.698 & .678 & .413 \\
& Within Groups & 1394.921 & 69 & 20.216 & & \\
& Total & 1408.620 & 70 & & & \\
\hline
\end{tabular}

Rata-rata kemampuan mmebaca untuk laki-laki adalah 17, 250 dan untuk perempuan adalah 16,371 sedangkan berdasarkan uji anova menunjukkan bahwa tidak ada perbedaan kemampuan membaca antara laki-laki dan perempuan ( $\mathrm{F} 0,678, \mathrm{p}>0,413$ ). Dengan demikian maka hipotesa pertama yang berbunyi kemampuan membaca siswa perempuan lebih tinggi dari kemampuan membaca siswa laki-laki di tolak, artinya bahwa kemampuan membaca antara siswa laki-laki dan perempuan tidak berbeda.

\section{Perbedaan kemampuan membaca di tinjau dari jenis sekolah}

Untuk mengetahui adanya perbedaan kemampuan membaca antara siswa SD dan MI bisa diuji dengan anava dan uji komparasi means dari masing-masing jenis kelamin. Hasil dari uji komparasi means adalah sebagai berikut

Tabel IV. Hasil mean kemampuan membaca berdasarkan jenis kelamim siswa SD/MI

\begin{tabular}{|l|l|l|l|}
\hline Jenis sekolah & Mean & $\mathrm{N}$ & Std. Deviation \\
\hline
\end{tabular}

71 Madrasah, Vol. 4 No. 1 Juli-Desember 2011 
Rifa Hidayah - Profil Kemampuan Membaca Siswa Kelas 5 SD \& MI

\begin{tabular}{|l|r|r|r|}
\hline SD & 17.2791 & 43 & 4.82713 \\
MI & 16.1071 & 28 & 3.88100 \\
Total & 16.8169 & 71 & 4.48588 \\
\hline
\end{tabular}

Tabel V. Analisis uji beda kemampuan membaca bedasarkan jenis sekolah

ANOVA Tablea

\begin{tabular}{|ll|r|r|r|r|r|}
\hline & \multicolumn{1}{|c|}{$\begin{array}{c}\text { Sum of } \\
\text { Squares }\end{array}$} & df & $\begin{array}{c}\text { Mean } \\
\text { Square }\end{array}$ & F & Sig. \\
\hline \begin{tabular}{ll|r|r|r|} 
Membaca * tipe \\
sekolah
\end{tabular} & $\begin{array}{l}\text { Between } \\
\text { Groups }\end{array}$ & 23.290 & 1 & 23.290 & 1.160 & .285 \\
& $\begin{array}{l}\text { Within } \\
\text { Groups }\end{array}$ & 1385.330 & 69 & 20.077 & & \\
& 1408.620 & 70 & & & \\
\hline
\end{tabular}

Berdasarkan hasil statistik uji beda menunjukkan rata-rata kemampuan mmebaca siswa SD sebesar 17.2791 dan siswa MI sebesar 16.1071. Sesuai hasil uji statsitik pada tabel di atas bahwa ditinjau dari jenis sekolah tidak ada perbedaan kemampuan membaca. Dengan demikian maka hipotesa pertama yang berbunyi kemampuan membaca siswa SD lebih tinggi dari kemampuan membaca siswa MI di tolak $(p=0,285>0,005)$. Artinya bahwa kemampuan membaca siswa yang berasal dari SD dan siswa yang berasal dari MI tidak berbeda.

72 Madrasah, Vol. 4 No. 1 Juli-Desember 2011 


\section{Rifa Hidayah - Profil Kemampuan Membaca Siswa Kelas 5 SD \& MI}

\section{E. PEMBAHASAN}

Hasil analisis menunjukkan bahwa kemampuan membaca siswa SD dan MI kelas lima tergolong rendah. Selain itu berdasarkan kemampuan membaca berdasarkan jenis kelamin (laki-laki dan perempuan) dan tipe sekolah (SD dan MI) menunjukkan tidak ada perbedaan.

Hipotesa pertama bahwa ada perbedaan antara laki-laki dan perempuan dalam kemampuan membaca di tolak. Hal ini karena kemampuan membaca bukan hanya dilihat dari jenis kelaminnya akan tetapi lebih di lihat dari faktor lingkungan sosial yang mencakup tentang perbedaan respon masyarakat antara anak perempuan dan laki-laki terutama dalam hal interaksi verbal (Aaron, 2008). Artinya bukan kodrat anak perempuan lantas pintar membaca di banding laki-laki akan tetapi jika perlakukan keduanya sama maka kemampuan mmebacnya juga cenderung sama.

Hasil penelitian ini senada dengan penelitian Maccoby dan Jaclin (Thalib, 2003) pada dasarnya tidak ada perbedaan antara laki-laki dan perempuan terhadap stimulus sosial, non sosial, persepsi, belajar dan memori, perbedaan itu lebih ditentukan oleh latar belakang budaya seperti dukungan sosial, pengasuhan orangtua. Contoh perbedaan laki-dan perempuan karena budaya sebagaiman hasil penelitian Wimbarti (1997) bahwa perempuan lebih mahir dalam kemampuan verbal karena perempuan dianggap lebih sesuai untuk tinggal dirumah, mmebaca buku atau bercakap-cakap dengan teman di rumah atau di rumah teman, sedangkan laki-laki dipandang sesuai untuk bermain-main, naik sepeda, main bola. Justru kemmapuan membaca yang berbeda itu karena anak perempuan lebih didorong untuk mampu dalam interaksi verbal sehingga kemampuan bahasa dan membacanya lebih terasah daripada laki-laki, sedang laki-laki lebih terasah kemampuannya dalam bidang matematika yang kurang membutuhkan kemampuan bahasa (Lyon, 1996; Mileer, 1993; Santrock, 2004; Sauve, 2005). Selain itu secara kultural, orangtua juga lebih protektif pada anak perempuan daripada laki-laki. Anak perempuan memiliki waktu lebih banyak untuk bergaul dengan orangtuanya, 


\section{Rifa Hidayah - Profil Kemampuan Membaca Siswa Kelas 5 SD \& MI}

sehingga anak perempuan memiliki pengalaman interaksi verbal yang lebih tinggi dibandingkan dengan anak laki-laki (Rofiudin, 2003).

Guru perlu mengupayakan berbagai aktivitas yang mendukung literasi anak, seperti menuliskan kata-kata di taruh di pokok kelas, atau papan pengumuman, atau papan pemajangan hasil karya siswa sehingga dengan mudah dibaca anak. Dengan anak sering membaca akan menambah penguasaan kosakata anak mendorong anak anak untuk senang dan aktif membaca membaca. Penelitian menunjukkan motivasi siswa meningkat ketika guru berkorabolasi langsung membacakan buku untuk anak dalam proses pembelajaran (Guthrie, et al., 2004). Guru yang lebih menekankan pentingnya ekspresi diri pada siswanya ternyata motivasi intrinsik siswa naik secara signifikan (Guthrie \& Alao, 1997).

Hipotesa kedua di tolak. Artinya jenis pendidikan dasar yang berasal dari sekolah yang berada di bawah naungan Diknas dan Kamenag tidak berbeda kemampuan membacanya. Hal ini bisa dijelaskan karena kurikulum bahasa Indonesia yang diterapkan di SD dan MI adalah sama baik dari segi materi maupun wktu pelaksanaan. Selain itu kemampuan membaca juga dipengaruhi oleh semakin lengkapnya fasilitas kelas sebagai pusat pembelajaran, serta ketersediaan materi membaca serta adanya kesempatan siswa untuk membaca maka tingkat kemampuan membaca siswa akan meningkat.

\section{F. PENUTUP}

Intinya bahwa membaca merupakan proses yang berkembang dan untuk mengembangkannya diperlukan upaya seperti memperkirakan dan mendorong literasi, menciptakan lingkungan yang kaya bahasa dengan banyak jenis tulisan yang beragam seperti buku, memodelkan membaca dengan berbagai pengalaman di papan tulis, menyediakan pusat membaca serta mengenalkan gambar, formasi huruf, poster sebagai alat komunikasi (Vygotsky, dalam Yayli, 2009). Lingkungan seperti itu akan merangsang munculnya proses belajar yang menyenangkan dan mempromosikan konsep tentang kelas sebagai kumpulan orang-orang yang belajar bersama-sama, atau konsep kelas

74 Madrasah, Vol. 4 No. 1 Juli-Desember 2011 


\section{Rifa Hidayah - Profil Kemampuan Membaca Siswa Kelas 5 SD \& MI}

sebagai pusat pembelajaran (Cooper, 2006). Persepsi anak terhadap lingkungan belajar berpengaruh terhadap motivasi membaca (Ryzin, 2011). Jika sekolah yang berasal dari SD dan MI memiliki lingkungan literasi di sekolah baik akan mampu meningkatkan motivasi siswa agar dapat memberikan semangat belajar yang tinggi bagi siswa, seperti tersedianya sarana buku yang memadai, perpustakaan yang lengkap, dan area untuk mengekpresikan hasil bacaan siswa di sekolah maka kemampuan membacanya akan baik, tak peduli dari jenis sekolah apapun.

Mengingat hasil tersebut yang perlu diupayakan adalah pengembangan beberapa sarana lingkungan kelas antara lain tersedianya perpustakaan kelas sebagai sarana untuk mempromosikan dan mendukung kemandirian dalam dalam membaca, seperti buku dari berbagai tingkatan kemampuan siswa, kaset, buku-buku, dan CD. Perpustakaan kelas atau sering disebut sudut baca membantu menumbuhkan minat, mengembangkan, dan mendorong siswa untuk membaca dan memanfaatkan seoptimal mungkin perpustakaan di sekolah untuk pembinaan kebiasaan membaca pada siswa.

\section{G. DAFTAR RUJUKAN}

Aaron, P.G., Joshi, M.R., Regina, G \& Bentum, K. E. (2008). Diagnosis and treatment of reading disabilities based on the component model of reading. Journal of Learning Disabilities, 41, 67-84.

Adams, K.D. (2009). The importance of multi-dimensional reading interventions in addressing the summer achievement gap. Unpublished doctoral dissertation, University of Tufts.

Alderson, C.J \& Bachaman, L.F (2000). Asessing reading. Cambridge; Crambrige University Press.

Ann, B. (2009). Developing language and literacy 3-8. Los Angeles. Sage publications Ltd

75 Madrasah, Vol. 4 No. 1 Juli-Desember 2011 


\section{Rifa Hidayah - Profil Kemampuan Membaca Siswa Kelas 5 SD \& MI}

Bender, W. N. (2004). Learning disabilities: characteristics, identification, and teaching strategies ( $5^{\text {th }}$ ed.). Montreal: Pearson Education Canada.

Bernard, M. E. (2006). It's time we teach social-emotional competence as well as we teach academic competence. Reading and Writing Quarterly, 22,103-119.

Bandura, A. (1986). Social foundations of thought and action: A social cognitive theory. Englewood Cliffs, NJ: Prentice Hall.

Bandura, A. (1997). Self-efficacy: The exercise of control. New York: Freeman.

BPS (2009). Persentase penduduk buta huruf menurut kelompok umur tahun 2003-2009 berdasar BPS-RI, Susenas 2003-2009. Badan Pusat Statistik Republik Indonesia. Retrivied on 7, Maret, 2011 from. http://www.bps.go.id/ tab_sub/ view.php? tabel=1\&daftar $=1 \&$ id_subyek= $28 \&$ notab $=2$.

Burns, P.C., Betty. D., Roe, E.P \& Ross. (1996). Teaching reading in today's elementary schools. Chicago: Rand Mc.Nally College Publishing Company.

Chapman, J. W., Tunmer, W. E., \& Prochnow, J. E. (2000), 'Early readingrelated skills and performance, reading self-concept, and the development of academic self-concept: a longitudinal study.' Journal of Educational Psychology, 92(4), 703-8.

Christen, H.M., (2005). A Survey of reading services provided to students with reading disabilities. Unpublished doctoral dissertation, Texas A \& M University.

Clora, A.M., (2006). An investigation of coping skills, locus of control, and quality of life in young adults with learning disabilities. Unpublished doctoral dissertation. Alabama: the Graduate Faculty of Auburn University.

Cooper, D.J. (2006). Literacy (4 th). New York: Houghton Mifflin Company 


\section{Rifa Hidayah - Profil Kemampuan Membaca Siswa Kelas 5 SD \& MI}

Crain, W. (2007). Theorits and development, concept and aplication (3rd ed).NJ Prestice Hall, Englewood Cliffs.

Crawley, S.J. \& Mountain, L. (1995). Strategies for guiding content reading. Boston: Allyn and Bacon.

Depdiknas, (2006). Kurikulum tingkat satuan pendidikan mata pelajaran bahasa Indonesia SD. Jakarta: Depdiknas.

Harris, A.L \& Smith, B.C. \& (1986). Reading Instruction. USA:Macmillan Publishing Company.

IEA TIMSS \& PIRLS (2007). PIRLS 2006 International Report. Retrivied on Maret, 1, 2008, From http:// pirls.bc.ed./pirls 2006/tech-rpt.Html.

Kartika, E, (2004). Memacu minat membaca siswa sekolah dasar. Jurnal Pendikan Penabur. 3 (III), 113-128.

Kim, J. (2004). Summer reading and the ethnic achievement gap. Journal of Education for Students Placed At Risk, 9, 169-188.

Kompas, (2010). Kaji ulang kurikulum bahasa indonesia. Retrivied on 5 Juni 2010, from www. kompas. Com.

Kumara, A. (2010). Mengasah keterampilan membaca pada anak melalui belajar atau bermain. Pidato Pengukuhan Guru Besar. Yogyakarta: UGM.

Kumara. A. (2002). Kualitas ekpresi bahasa tulis siswa SD. Disertasi Doktor Tidak Diterbitkan. Yogyakarta: UGM.

Lamb, P., \& Richard, A. (1976). Reading; Foundations and instructional strategies. Belmonts: Wadsworth Publishing Company, Inc.

Law, Y-K, (2008). The relationship between extrinsic motivation, home literacy, classroom instructional practices, and reading proficiency in second-grade Chinese children. Research in Education. 80, 37-51.

McLoughin, A.J., \& Lewis B. R., (2008). Assessing special students. London: Charles Emerrill Publishing Company.

77 Madrasah, Vol. 4 No. 1 Juli-Desember 2011 


\section{Rifa Hidayah - Profil Kemampuan Membaca Siswa Kelas 5 SD \& MI}

Mendiknas (2011). Kemampuan Baca Siswa Indonesia Masih Rendah. Education. Rabu, 02/03/2011 retrivied Mei, 20, 2011 from http://today.co.id/read/2011/03/02/13992.

Miller, W.H., (1993). Complete Reading Disabilities Handbook. United State of America: John Wiley \& Sons.

Moores, T.T, Chang, JT \& Smith, DK (2006). Clarifying the Role of SelfEfficacy and Metacognition as Predictors of Performance. Database for Advances in Information Systems; Spring 2006; 37, 2/3, pg. 125-132

Nawangsari, F.A., \& Suprapti, V. (2007). Identifikasi dan model intervensi gangguan kesulitan belajar pada siswa sekolah dasar di Surabaya. Laporan penelitian tidak dipublikasikan. Surabaya:Unair

Nelson, M, J. (2005). Affective dan motivational responses of upper elementary middle school students with reading disabilities to two intensive reading interventions. Unpublished doctoral dissertation: University of Indiana.

Noor, I (2010). Model Membaca, Menulis, dan Berhitung di Sekolah Dasar. Puslitjaknov, Balitbang Depdiknas, Jakarta.

OECD, PISA 2009. Results: Executive Summary. Retreived on December 7, 2010, from: http://dx.doi.org/10.1787/888932343342

OECD/Organization for Economic Coorperation and Development, (2007). Excecutive summary PISA 2006. Retreived on Juni 10, 2010 from: www. Pisa Oecd. Org.

Papalia, D.E., Olds, S.W. \& Feldman, R. D. (2001). Human development. New York: McGraw-Hill Companies, Inc.

Park, H. (2008). Home literacy environments and children's reading performance: a comparative study of 25 countries. Educational Research and Evaluation .14,(6),489-505.

Petscher, Y \& Kim, S.Y (2010). Does growth rate in oral reading fluency matter in predicting reading comprehension achievement. Journal of Educational Psychology. 102 (3), 652-667. DOI: 10.1037/a0019643

78 Madrasah, Vol. 4 No. 1 Juli-Desember 2011 


\section{Rifa Hidayah - Profil Kemampuan Membaca Siswa Kelas 5 SD \& MI}

Puslitbang. (2006). Pendidikan Agama dan Keagamaan. Jakarta: Diknas

Reuda, R. (2011) Cultural prespective in reading. In handbook of reading research. New York: Tailor \& francis, 84-104.

Rofiuddin, A \& Zuhdi, D (2000). Pendidikan bahasa dan sastra Indonesia di kelas tinggi. Jakarta: Diknas.

Rofiuddin, A. (2003). Faktor kreativitas dalam kemampuan membaca dan menulis siswa sekolah dasar. Bahasa dan Seni, 31 (2), 172-196.

Ryan M.R \& Deci, E.L (2000). Intrinsic and extrinsic motivation: Classic definition and new directions. Journal Contemporary Educational Psychology, 25, 54-67

Ryzin, V.J.M., (2011). Motivation and reading disabilities, In Handbook Reading Diasbility Research. Routledge, New York, 242-250.

Shaleh, Abdul Rachman, (2004) Madrasah dan Pendidikan Anak Bangsa Visi, Misi dan Aksi. Jakarta: PT Raja Grafindo persada.

Syafi'e, I (1999). Pengajaran membaca di kelas kelas awal SD: Pidato pengukuran guru besar dalam bidang ilmu pengajaran bahasa Indonesia, Malang; FPBS UM.

Syafie, I. (1993). Trampil berbahasa Indonesia. Petunjuk guru bahasa Indonesia. Jakarta: Balai Pustaka.

Santrock, W. J., (2004). Educational psychology. New York. McGraw-Hill Company.Inc.

Tarigan, H.G. (2008). Membaca sebagai suatu keterampilan berbahasa. Bandung: Angkasa

Torgesen, J. K. (2000). Individual differences in response to early interventions in reading: The lingering problem of treatment resisters. Learning Disabilities Research \& Practice, 15, 55-64.

Vaughn, S., Linan-Thompson, S., \& Hickman, P. (2003). Response to instruction as a means of identifying students with reading/learning disabilities. Exceptional Journal. 69, (4), 391-409.

79 Madrasah, Vol. 4 No. 1 Juli-Desember 2011 


\section{Rifa Hidayah - Profil Kemampuan Membaca Siswa Kelas 5 SD \& MI}

Vygotsky 1. S.(1978). Mind in Society The Developmentof Higher Psychological Processes. Cambridge, Massachusetts.

Wang, J., \& Guthrie, J. T. (2004). Modeling the effects of intrinsic motivation, extrinsic motivation, amount of reading, and past reading achievement on text comprehension between U.S. and Chinese students. Reading Research Quarterly, 39 (2), 162-186.

Woodward, JL. (2002). Identifying reading-disabled children: An alternatif approach. Dissertation, University of Carbondale.

Yayli, D. (2009). New roles for literacy teachers in the age of multiliteracies:A sociocultural perspective. Procedia Social and Behavioral Sciences. 1, 206-209.

Yuliati. (2008). Pengembangan paket panduan pembelajaran membaca dan menulis dengan pendekatan holistis bagi siswa berkesulitan belajar di SD. Disertasi tidak dipublikasikan. Universitas Negeri Malang.

Yusuf, C.F. (2006). Revitalisasi Madrasah, Jakarta: Puslitbang Pendidikan Agama dan Keagamaan

Yusuf, Suhendra. (2006). Perbandingan gender dalam prestasi literasi siswa indonesia. Universitas Pendidikan Indonesia.

Zuhdi, D., Sukamto \& Suryanto (2002). Pengembangan alat ukur peringkat ketrampilan membaca, menulis dan matematika pada jenjang sekolah dasar. Laporan Penelitian. Yogyakarta: UNY

80 Madrasah, Vol. 4 No. 1 Juli-Desember 2011 